Tamboukou, Maria.2020. 'Feeling the real: the non-nomadic subject of feminism. Theory, Culture and Society', forthcoming

\title{
Feeling the real: the non-nomadic subject of feminism
}

Maria Tamboukou, University of East London, UK

\begin{abstract}
Nomadism as a spatial concept denoting uncharted movements has opened up non-static ways of theorizing the subject in feminist theory and beyond. But it seems that the nomads of the real world and their torturing wanderings today, have irrevocably challenged the romance of unregulated movement and force us to radically rethink the very concept of nomadism itself. In this paper I address the aporias that women's entanglement in current mobility assemblages has raised in the ways we understand and imagine the subject of feminism. In doing so, I experiment with the concept of the non-nomad as an emergent figuration that retains the radicalism of nomadic theories, while pointing to their margins, shadows and exclusions.
\end{abstract}

Key words: the real, mobility assemblages, non-nomad, radical solitude, displaced women

The non-philosophical process of describing and rigorously explaining a reality is one that observes the effects of the real, reacts to the 'workings of the real' which resides behind the conceptual or discursive phenomenon that represents it, and builds its own syntax, which is then subjected to the real (Kolozova 2014, 3).

Embarking on the theoretical journey of Francois Laruelle's 'non-philosophy', Katerina Kolozova has provoked us to challenge philosophical thought's colonization of 'the real $^{1}$; instead she has urged us to approach the subject (amongst other concepts), not as a construed figure or even map of positions that can only think itself, but rather as a radical concept, 'an instance' that can enable thought to align with the real, instead of absorbing it in the totality of any system of linguistic representation and/or meaning.

But how can one 'correlate only with the real and in an immanent way' (ibid.,4) following Kolozova's trails in 'non-philosophy'? It is here that the figuration of 'the nomadic subject' (Braidotti, 1994, 2011) has recently come to haunt me as a concept that needs to be revisited and radicalized. Throughout my work I have repeatedly drawn on the nomadic subject as a useful figuration of female subjectivity (see Tamboukou 2003, 2009, 2012). Nomadism as a spatial concept denoting uncharted 
Tamboukou, Maria.2020. 'Feeling the real: the non-nomadic subject of feminism. Theory, Culture and Society', forthcoming

movements seemed to facilitate non-static ways of theorizing the subject and his/her relations to the world and to others. But it seems that the nomads of the real world and their torturing wanderings today, have challenged the romance of unregulated movement and force us to radically rethink the very concept of nomadism itself.

In engaging with questions of the real, I draw here on Alfred North Whiteheads' organic awareness of reality (1985). In Whitehead's realism, and his famous thesis against 'the bifurcation of nature', there is no gap between the scientific conception and the subjective experience of the world $(1964,30)$. As we emerge from the world and not the world from us, the real that has conditioned our being-in-the-world and our very ability to think, is continually urging us to respond to the questions it raises and to react to the necessities it creates, no matter how chaotic or ungraspable they are.

The question I therefore raise in this paper is whether nomadism has become a concept irreparably infected with the unbearable heaviness of those who are not able to move and cross borders and boundaries - the dark side of the moon of mobility. To put it simply: can we still use the nomadic subject in the era of the so called 'refugee crisis' that has uprooted millions of people across the globe and has forced them to take up nomadic paths as the only feasible way of going on living? Here it is important to note that the notion of the 'crisis' is debated and contested in current bodies of literature as a discursive construct in the process of restricting global mobility (see Zavos 2017; Carastathis et al. 2018). As Donna Gabaccia has argued, 'historians of migration view human movement as an ordinary, rather than exceptional, dimension of human life and as an almost universal human experience' $(1999,1115)$. But what has changed in the current flows of forced displacement is that in January 2016 women and children on the move outnumbered adult men for the first time comprising $60 \%$ of migrants crossing into Europe. ${ }^{2}$ This unprecedented phenomenon of women's mobility in the wilderness raises the question: how can the feminist figuration of the nomadic subject enable us to grasp the lived experiences of women entangled in global mobility assemblages?

In introducing the second edition of Nomadic Subjects, Braidotti has importantly noted that 'the central concern for my nomadic subject is that there is a noticeable gap between how we live [...] and how we represent to ourselves this lived existence in theoretical terms and discourses' $(2011,4)$. In this light, nomadic subjectivity is a process that should be taken 'as ethically accountable and empowering.' (ibid.) But how can this be done? This is the question that I want to take up in this paper. While I have been inspired by Braidotti's philosophical figuration of the nomadic subject, I also want to consider the implications of using words and names that have become unbearably heavy within the geopolitical contexts of our lived existence.

'There is a forcible affect of language, which courses like blood through its speakers', Denise Riley has written $(2005,1)$, pointing to the force of language to wound beyond consciousness, recognition and analytical thinking. Moreover, feminist theorists have persuasively argued that naming is a political act, one that is based on mutual recognition. (see Sheman 1983, Braaten 2002). To put it simply, the names that we 
give and the words that we use not only express, but also constitute the real. Drawing on Ludwig Wittgenstein's philosophy of language, Jane Braaten has observed however that there are no literal or fully determinate meanings of words and sentences and therefore viable alternatives are always possible $(2002,176)$. Since naming is an important political form of recognition, albeit not fully determinate, what I want to contemplate in this paper is the necessity or desirability of a shift in naming as a way of recognising displaced women's' right to have a place to live.

In light of the above, in this paper I problematize the nomadic subject, both as a concept and as a name-a descriptor of a subject position. My argument is that despite its radical genealogy in feminist theory and politics, the figuration of the nomad cannot correlate with the lived experiences of displaced women in the current geopolitical context. Although nomadism is still a component entangled in current mobility assemblages, its cartographies unveil different modalities of wanderings, other tracks, traces and sea crossings to be followed and understood.

The paper unfolds in five sections: first I revisit Braidotti's theorization of the nomadic subject by exploring critiques and contestations of her figuration. I particularly focus on Édward Glissant's notion of the errance-errantry as a line of thinking, decolonizing histories and geographies of nomadism. In the second part I question the nomadic subject as a descriptor, by looking at the politics of naming through feminist interpretations of Wittgenstein's 'language games'. In taking language as a practice I point to its possibility to wound and marginalize beyond consciousness, analytical subtleties and authorial intentions. Then I deploy the notion of mobility assemblages to consider the real of migrant and refugee women's wanderings. In doing so I make connections with some aspects of Laruelle's non-philosophy that Kolozova has deployed in her theorization and challenge of the post-postructuralist subject of feminism. ${ }^{3}$ My point here is that philosophical abstractions run the risk of absorbing the real of which they speak and thus losing sight of its actuality. In the fourth section I follow stories of displacement drawing on feminist approaches to the existential forces and political significance of narratives, particularly when they unfold within mobility assemblages. In the last section, I suggest the non-nomad as an emergent figuration that keeps some of the strengths and radical potentialities of nomadic thinking while acknowledging the nomadic subject's limitations, marginalizations and omissions, in its encounter with the real.

\section{Thinking nomadism: a contested notion}

Rosi Braidotti's figuration of 'the nomadic subject' has been a radical intervention in the way feminism has theorized subjectivity. Nomadism runs as a red thread throughout her work, weaving together her trilogy of Nomadic Subjects (1994), Metamorphoses (2002) and Transpositions (2006). While revisiting the first edition of Nomadic Subjects (2011), Braidotti has also offered Nomadic Theory (2012) as a comprehensive volume encompassing the concepts, formulations and figurations that emerge from her overall philosophical work. While acknowledging the critical archive of knowledges that Braidotti has created around her take of nomadism, in this paper I will focus on 'the nomadic subject' as a philosophical and political figuration unfolding throughout her corpus, as briefly outlined above. 
Spaces, places, gendered bodies and movement are at the heart of the embodied and embedded conceptualization of 'the nomadic subject'. But while Braidotti has tried to ground and sex the abstract figure of the nomad in Deleuze and Guattari's philosophical work (1988), she has nevertheless created her own abstractions, as I will further argue in this section. In introducing her figuration, Braidotti has highlighted its mythical traits and has pointed to its connections to a Spinozist take of political imagination-imagining a different world so that social change can become an actuality: 'the nomadic subject is a myth, or a political action, that allows me to think through and move across established categories and levels of experience: blurring boundaries without burning bridges', she has written $(2011,26)$.

Despite its mythical and metaphorical traits however, the nomad acknowledges the real by pointing to the bodily, material and spatial roots of subjectivity. Nomadic subjects are subjects in transition. They are not characterized by homelessness, but by their ability to recreate their homes everywhere. As Deleuze and Guattari have put it 'the nomad has a territory; distributes himself [sic] in a smooth space; occupies, inhabits, holds that space' $(1988,380)$. Distributed in a smooth space, the nomadic subject is not permanent: it is constituted by continuous shifts and changes, which have their cycles of repetition and recurrence. The nomad is not unified but is not completely devoid of unity either. The nomad passes through, connects, circulates, moves on; she or he makes connections and keeps coming back. (ibid.) It is, however, in passing between these points that the nomad enjoys the freedom of movement. The life of the nomad is the going between, 'the intermezzo' (ibid). Nomadic subjects cannot be integrated into established social structures and react critically to the discourses and practices that have set the conditions of their existence in this world.

In the light of Deleuze and Guattari's nomadology (1988), Braidotti has thus imagined 'nomadic consciousness as a form of political resistance to hegemonic and exclusionary views of subjectivity', $(2011,58)$; she has further related it to the Foucauldian notion of counter-memory that has the possibility of enacting a rebellion of subjugated knowledges $(2011,60)$. Travelling is not essential in the condition of the nomad. As Deleuze and Guattari have put it, 'the question is what in nomad life is a principle and what is only a consequence' $(1988,380)$, and in this line of analysis the nomad's transition from point to point is indeed a consequence, 'a factual necessity', while 'it is false to define the nomad by movement'. Braidotti has therefore noted that 'it is the subversion of set conventions that defines the nomadic process, not the literal act of travelling', adding that 'some of the greatest trips can take place without physically moving from one's habitat' $(2011,26)$. In this light, nomadism is not a situation of being, but of becoming: 'nomadic shifts designate therefore, a creative sort of becoming, a performative metaphor that allows for otherwise unlikely encounters and unsuspected sources of interaction, of experience and of knowledge' (ibid., 27).

Braidotti has stressed the interdependence of travelling and nomadism in an attempt to respond to certain critiques that have problematized the use of travel metaphors in contemporary social and cultural studies and in feminist theories in particular. ${ }^{4}$ In 
addressing reservations about the romanticizing of the notions of deterritorialization and the nomad, Braidotti has argued that the 'radical nomadic epistemology Deleuze and Guattari propose is a form of resistance to micro-fascisms in that it focuses on the need for a qualitative shift away from hegemony, whatever its size and however "local" it may be' $(2011,26)$. Nomadism can thus be conceived as an assemblage of spatial tactics against borders and movement regulation.

Nomadic tactics keep erupting all over the globe today. Yet, while I can see the radicalness of nomadic theories, I think that critiques and reservations about the absence of specific historical and cultural context within which nomads should be situated and analyzed are particularly pertinent today. As Braidotti herself has noted: 'what we need [...] is higher degrees of accuracy in accounting for both the external factors and the internal complexity of nomadic subjectivity' $(2011,4)$.

In thinking about the material, spatial and historical conditions of nomadism, I consider here Glissant's reservations vis-à-vis the supposedly radical and anticonformist aspects of nomadism in Deleuze and Guattari's configuration. ' ${ }^{5}$ Is the nomad not overdetermined by the conditions of his [sic] existence [...] is it not a form of obedience to contingencies that are restrictive?' Glissant has asked $(2010,12)$ In raising such questions Glissant draws a distinction between 'circular' and 'invading, or arrowlike' nomadism. 'Circular nomadism' emerges out of necessity: groups move when certain territories are exhausted and there is a need for new resources to be found. In this sense, 'circular nomadism' is not a spatial practice against settlement but rather a tactic of survival, Glissant notes (ibid.). 'Invading nomadism' on the other hand has historically been an aggressive strategy 'whose goal was to conquer lands by exterminating their occupants' (ibid.) 'Circular nomadism' is here juxtaposed to 'arrowlike nomadism', which not only does it not oppose settlement, it is actually 'a devastating desire for settlement'. (ibid) What both 'circular' and 'arrowlike' nomadisms share however, is a defiance of 'roots'. According to Glissant, this is the conjunction that has made nomadism the enemy par excellence of the nation states of modernity.

Going against the root is indeed the core of errance [errantry], a notion that Glissant offers to denote spatial, cultural, existential and political wanderings. Errance in Glissant's configuration is interwoven with Deleuze and Guattari's notion of the rhizome: 'Rhizomatic thought is the principle behind what I call the Poetics of Relation, in which each and every identity is extended through a relationship with the Other', he writes. (Glissant 2010, 11) Errance then is a different mode of mobility and its trajectories are neither arrowlike, nor circular, as in the two forms of nomadism outlined above. Moreover, as a different mode of rootedness, errance is not idle roaming either: 'in errantry one knows at every moment where one is at every moment in relation to the other', Betsy Wing has commented $(2010, x v i)$ since 'errantry' encapsulates the relationship between trauma, memory and movement. In Glissant's poetics, the traumatic experience of crossing the sea in the slave ship becomes a material mnemonic trace that grounds and supports rising from the ruins and beginning again: 'the entire ocean, the entire sea gently collapsing in the end into the pleasures of sand, make one vast beginning, but a beginning whose time is marked 
by these balls and chains gone green' Glissant writes, reminding the reader of all those slaves, who were thrown into the sea, every time slave ships were being chased. $(2010,6)$ Errance then 'lies between a notion of fixed identity, rooted in an ancestral past (the movement back to Africa) and a purely fluid subjectivity that precludes communities of affinity and shared horizons of meaning' Max Hantel has commented. (2012, par.37) By going against totalitarian roots without rejecting rhizomatic connections, errance is entangled in Glissant's Poetics of Relation as movement and as a transformative mode of history.

As a notion emerging from the depths of Glissant's archipelagic thought - la pensée archipelique - errance is thus juxtaposed to the territorialities of nomadism - la pensée continentale; it is an image of thought surrounded by ambivalence and fragility, the ever-eluding feeling of the sea. But even when he uses the sea as the plane of consistency for his errance, Glissant makes differentiations: 'Compared to the Mediterranean, which is an inner sea surrounded by lands, a sea that concentrates [...] the Caribbean is in contrast, a sea that explodes the scattered lands into an arc', he writes $(1997,33)$. The nuances and subtleties of Glissant's analytics are a good example of the cartographic approach that Braidotti proposes in supporting the pragmatism of her nomadic thesis, but never really stages in her own work.

Moreover, it is interesting to note that although the Poetics of Relation was first published in France in 1990, there is not a single reference to Glissant in the first edition of the Nomadic Subjects in 1994, and only a quick reference in the second edition of 2011. In situating her analysis on a plane of thinking where race discourses have been contested, Braidotti argues that she follows Glissant in positing multilocality as a positive stance vis-à-vis the negativity of loss and pain $(2011,80)$. I think an important encounter could have happened between errance and nomadism, the archipelago and the continent, la pensée archipelique and la pensée continentale, but this relation is never taken up in Braidotti's analysis. This is despite her argument that rather than thinking about separate concepts we should consider processes: 'flows and interconnections' between them. $(2012,14)$

It is therefore in this lacuna, the in-between space of errance and nomadism that I have situated my analysis of stories of forced displacement. As I will discuss later on in the paper, Glissant's mapping of different modalities of nomadism, always historically and geographically specific, grounds philosophical abstractions and figurations and opens up analytical paths for understanding migrant and refugee women's movement in the wilderness. But as I have already noted above, in this paper I interrogate 'the nomadic subject' not only as a figuration, but also as a name, a word, a descriptor. I thus now turn to the next section, where I consider the power of language in constituting realities and wounding beyond consciousness and authorial or analytical intentions.

\section{Nomadism and the politics of naming}


What I have shown in the previous section is that nomadism is a rich philosophical notion, as well as a useful tool in theorizing female subjectivities as processes, ongoing becomings. Nomadism, however, also carries controversial and ambivalent meanings vis-à-vis the historical, geopolitical and cultural realities it has emerged from. Moreover, even when the nomad is taken as a figuration or a metaphor, the constitutive power of myths, words and names should not be downplayed or bracketed. Here, Foucault's famous statement that discourses should be taken 'as practices that systematically form the objects of which they speak' $(1991,49)$ is particularly pertinent.

In the context of considering the power of language and discourse Baaten has thus argued that the feminist practice of naming our own experience [subjectivity included] might well be regarded as an emergent [Wittgensteinian] language game' $(2002,187)$. In doing so she has particularly highlighted Wittgenstein's exposition of the dynamically social character of meaning arguing that there are powerful nonliteralist components in Wittgenstein's philosophy of language that might be useful for a feminist radical critique of language. As Baaten has succinctly put it: 'If Wittgenstein's concept of language games allows us to contrast actual usage with as yet unrealized language games, it could be useful in articulating the underlying philosophical commitments of the politics of naming' $(2002,181)$. It is thus the possibilities and constraints of emerging language games that I want to interrogate through problematizing the political salience of the nomad as a descriptor of a subject position, even if the latter is being transposed and/or in the process of becoming other.

While writing about material metamorphoses and transpositions Braidotti (2002, 2006) has noted that 'being a nomad, living in transition, does not mean that one cannot or is unwilling to create those necessarily stable and reassuring bases for identity that allow one to function in a community' $(2011,64)$. She has further added that nomadic consciousness is not about not having an identity at all, but rather 'in not taking any kind of identity as permanent' (ibid). In doing so, she has pointed to moments when 'the nomadic subject' inhabits a subject position, even if this is only momentary and provisional. Moreover, in Metamorphoses Braidotti has extensively deployed the trope of the 'glue' - discursive, symbolic, imaginary, invisible and/or psychic - holding together the fragments of her nomadic subjects. In doing so she has looked for unifying instances in the otherwise non-unitary subject of poststructuralist feminist theories, Kolozova has pithily commented $(2014,26)$.

Given that 'the nomadic subject' does indeed emerge as a descriptor of a subject position in Braidotti's analysis, as well as in other takes of it in the relevant literature (see Tamboukou 2003, 2009, 2012), challenging its power to name and therefore create the subjects of which it speaks, is both important and urgent. If we follow Wittgenstein's suggestion that language is exclusively a social activity, as well as his proposed method of explaining meaning as use, the context within the nomadic subject is configured becomes crucial. What should therefore be interrogated is not only what the nomadic subject means, but also the practice of language: what the nomadic subject does. 
Tamboukou, Maria.2020. 'Feeling the real: the non-nomadic subject of feminism. Theory, Culture and Society', forthcoming

Virginia Woolf's famously statement that 'as a woman I have no country, as a woman I want no country, as a woman my country is the whole world' $(1978,109)$ has been flagged up in the rich body of feminist literature that has looked at dangerous liaisons between gender, place and all kinds of nationalisms. Braidotti has taken issue with this form of 'planetary exile' and celebration of 'homelessness, countrylessness, of not having a common anchoring point' $(2011,56)$. It is precisely in her attempt to embed female subjectivity in Adrian Rich's 'politics of location' that she has come up with the figuration of the nomadic subject. When however, she uses 'the passport' to denote women's many possibilities for continuous movement and serial spatial, cultural and emotional attachments, the frame of reference, the mythic correlation or the metaphoric trait for even the feminist nomad, who 'has no passport-or has too many of them' (Braidotti 2011, 64) is mostly a white, Western, and privileged subject.

Indeed, in the era of walls, iron fences, mass drownings and authoritarian travel bans, who can choose to have or not to have a passport, even if the nomad is taken as a figuration of the subject? As Braidotti has observed about mobility in the globalized network society of advanced capitalism, 'goods, commodities and data circulate much more freely than human subjects or in some cases, the less than human subjects, who constitute the bulk of asylum seekers and illegal inhabitants of the world' $(2011,6)$.

Although Braidotti has taken issue with previous critics of 'the passport trope' (Boer 1996, Gedalof 1999, cited in Braidotti 2011, 11) her response is not persuasive. It is not enough to argue that 'having no passport or having too many of them is neither equivalent, nor is it merely metaphorical' $(2012,14)$ and that 'figurations attempt to draw a cartography of the power relations that define these respective positions' (ibid.). I can't see how more abstractions can resolve philosophy's clashes with the real and I feel that Braidotti's responses to critiques get entangled into a theoretical discourse that seems to become self-referential, while losing sight of the real, as 'nonphilosophy' has warned us against. To be able 'to align with the real' (Kolozova, 2014, 4), we need to take a step back and reorient ourselves in the world of which we speak.

As I argue throughout the paper, stories have the power of grounding abstractions and help us remake connections with the real and the web of human relations. In this context, when recounting her experiences of escaping Sierra Leone to find a job in Greece, Hanna simply told me that she didn't even know about the requirement to have a passport in order to travel: 'the consul told me that I needed a passport; where could I go for passports, I didn't know how to do it with my government, I had never thought of it, you understand'. ${ }^{6}$ The 'passport' in the context of Hanna's story was an unknown object until the moment she was told that she needed it and even when she learnt about its value and function, she didn't have the knowledge or the money to obtain it. Moreover, when she eventually came to Greece, she deeply desired to acquire a fixed identity and claim citizenship rights. The nomad who 'never takes on fully the limits of one national, fixed identity' (Braidotti 2011, 64) is against privileged in terms of survival and mobility. The archive of stories in my current research (Tamboukou 2018, 2020a, 2020b) bursts from displaced women's desire to register as asylum seekers and get a legal status in the country they have managed to reach: 
'without identity, you don't have any right, you are nothing', Nadia, a young Afghan woman, simply put it in her story ${ }^{7}$. Words and meanings circulate and translate differently; they always exceed the speaker's or writer's intentions, so we need to be more sensitive in how we deploy them and with what effects.

Moreover, figurations are always expressed in words and words taken as practices rather than linguistic signs can wound, as their use presupposes material, spatial and administrative conditions that are only available to some on the basis of the exclusion of many others. As Christine Koggel has noted, 'words have functions in purposeful activity in the same way that particular objects have functions' $(2002,237)$. Drawing on lan Hacking's notion of 'dynamic nominalism' (1986) that looks into the history of how names constitute human beings and the acts they are labeling, Koggel (2002) has suggested that when we create figurations, such as 'the nomadic subject', we actively intervene in shaping the world we describe and the groups we name. Nancy Baker (2002) has further argued that exclusions in language games create scapegoats that ultimately define the groups or collectivities they are excluded from, be they real or symbolic.

In this sense the material, embodied and situated positions of migrant and refugee women crossing borders with too many [fake] passports or no passport at all, challenge the figuration of the nomadic subject of feminist theory. As Braidotti has pointed out, 'figurations are not figurative ways of thinking, but rather materialistic mappings of situated, i.e., embedded and embodied, social positions' $(2011,4)$. Moreover, Wittgenstein has called our attention to the effects of using language: what it is we actually do in coining concepts, using or refusing to use terms and notions, reading and rewriting documents, developing theories and unfolding textual practices. It is this sensibility to embodied and embedded figurations, as well as to the constitutive power of words that I want to consider by sticking to the project of walking alongside the real.

\section{Mobility assemblages and entanglements with the real}

We have recently witnessed a plethora of textual and visual representations of 'migrant and refugee women travelling alone' - alone taking the meaning of not being accompanied by men-since the majority of these women 'travelling alone' are really women travelling with their children, both born and unborn. The case study of Farah illustrates the language paradoxes used for the representation of women 'travelling alone': 'Farah is an Afghan refugee travelling alone through Europe with her eight children, seven of whom are girls under the age of $17{ }^{\prime} .{ }^{8}$ Newspaper articles but also official organizational and institutional reports are abounding with information and numbers about women's mobility en masse, without the protection of men. Here discursive formations and representations of the real tend to hijack and absorb it, creating according to Kolozova an 'amphibology' between representation and the real.

'Amphibology' is a concept that Kolozova borrows from Laruelle's philosophical vocabulary to denote the phenomenon where 'thought and the real [...] become 
indiscernible from each other' $(2014,6)$. Kolozova argues that this is a process that ultimately distorts the real and absorbs and erases its effects, to the point that the real is ultimately cancelled and what remains is only 'speculative realism' $(2014,1)$. To put 'amphibology' in the context of this paper then, in developing sophisticated and nuanced analyses around the figuration of the nomad we run the risk of distancing feminist thought and praxis from the harsh conditions of global border crossings in the context of the what I have configured as mobility assemblages.

In deploying the notion of the mobility assemblage, I draw here on Stephen Castles' argument that the distinction between migration as voluntary movement and asylum as coercion does not stand, since migratory movements across the globe have historically been triggered by wars, regional conflicts, national and international politics, as well as local and global economic dynamics. (2006) However, while Castles talks about the migration/asylum nexus as a divide with blurring and porous boundaries, my argument is that global mobilities have always been much more complex than even unstable binarisms. Moreover, they can never be pinned down, or stabilized, let alone ordered or controlled. They can only be mapped provisionally, since they keep changing and moving. In this context, mobilities should be theorised as assemblages, Deleuze and Guattari's (1988) concept that highlights material and symbolic entanglements of components through which provisional entities and relations emerge and intra-act. ${ }^{9}$

Theorized through the lens of assemblage thinking, mobility emerges as a complex entanglement: some of its components could include molar or macro formations, like wars, local conflicts, labour under conditions of racial capitalism, global trade, patriarchal regimes and harsh border practices, in short the macro-relations that Castle's (2006) asylum/migration nexus has identified. But even when they do include molar formations, a closer attention to the functioning of these assemblages shows that they are not as stable and coherent as they appear to be. As Deleuze has put it, 'the assemblage's only unity is that of co-functioning: it is a symbiosis, a 'sympathy'. (Deleuze and Parnet 1977, 52). This does not mean that molar formations like wars or capitalism are downplayed as powerful institutions within assemblage analytics. What assemblage thinking offers is 'a sustained account of the different ways in which orders endure across differences and amid transformations, in addition to a sensitivity to how orders change and are reworked' (Anderson et al, 2012, 173). It is this 'additional' sensitivity to how orders, but also how concepts change that assemblage thinking facilitates.

What are the implications of working with assemblage theories then? A central task of the analysis would be to make specific cartographies of situated phenomena and problems, trace the connections they make in order to configure emerging new formations, but also follow their 'lines of flight', since for Deleuze and Guattari (1988), society is not so much defined by its molar formations and their dialectic oppositions but rather by what has escaped them (ibid., 216). And although each story is just a singularity, the already significant body of literature on facts and figures of migration and forced displacement across the glob ${ }^{10}$ fully supports and historically contextualizes lived experiences of mobility, what François Laruelle (2000) calls, 'le 
Tamboukou, Maria.2020. 'Feeling the real: the non-nomadic subject of feminism. Theory, Culture and Society', forthcoming

vécu.' What I therefore suggest is that charting mobility assemblages responds to a body of feminist critiques that have pointed to the colonial underpinnings of abstract mobility in philosophies of nomadism. (see Wuthnow 2002, Yountae 2014)

Situated within assemblage theories then, the figuration of the nomad encompasses components of a radical conceptualization of subjectivity, but it is still outside the syntax of the real'. As Kolozova explains, the latter is a process in Laruelle's 'nonphilosophy' that attempts to chart the real in a rigorous way; it is affected by the immanence of the real and rejects a-priori philosophical decisions or gestures that would obscure and ultimately substitute it $(2014,9)$. Engaging with Laruelle's nonphilosophy might therefore be a way of addressing the limitations and constraints of using the nomad as a descriptor, without altogether rejecting the philosophical figuration and the radical paths it has opened in feminist theorizations of subjectivity. But how is non-philosophy to be understood?

Non-philosophy for Laruelle 'only claims to succeed the faith and authority of philosophy, never to deny its reality, nor to refuse it at least a "relative" autonomy" (2013, xxi). In this light, 'non-standard philosophy' is another term that Laruelle has used to configure his theoretical work, pointing to its emergence from the philosophical grounds of 'radical immanence' (ibid.). In doing so Laruelle proposes a unified theory of science and philosophy, wherein the real 'is immanent to itself rather than to a form of thought' (ibid., 5, emphasis in the text). As John Mullarkey and Anthony Smith have noted, Laruelle's idea is that 'thought should think of itself as immanent to the real' $(2012,2)$. In this context instead of pretending to represent, become or transcend the real of which it speaks, non-philosophy admits that while it will never ultimately reach the real, it will maintain certain relations with it: will walk along it, will speak to it, will try not to lose sight of it and will finally attempt to transform it:

Non-philosophy must remain an explicative theoretical hypothesis: it does not confuse itself with its object, with experience [but] it must at least also transform experience [...] it is in a perpetual state of producing novelty; of opening and rectifying a specific space of knowing without confusing itself with the reality to be described. (Laruelle 2013, 11)

When Braidotti writes that 'in my work on nomadic thought I adopt a creative redefinition of thinking that links philosophy to the creation of new forms of subjectivity' $(2012,5)$ she seems to conflate her figurations with the objects/subjects of which she speaks, even when she claims to take them as embedded and embodied. How can philosophy create new forms of subjectivity? Philosophical thought can only respond to or walk along new forms of subjectivity that emerge from their entanglement in the world, not the other way around. We emerge from the world and not the world from us, Whitehead keeps reminding us $(1985,88)$, while Isabelle Stengers insists on a sensibility towards 'the experience as we experience it' (2008, 109). 
Given the centrality of the philosophy/science relationship in Laruelle's theorization, attending to the emergence of the real and tracing its unfolding is at the heart of the non-philosophical project. In devising a research project wherein, I have asked migrant and refugee women to narrate their experiences of travelling to Greece, I have thus attempted to build a bridge between an influential figuration in feminist philosophy and the real of which it speaks. (see Tamboukou 2020a) While my take of the real follows Whitehead's organic realism (1985), I nevertheless agree with Laruelle and Kolozova that the real can never be fully grasped, mirrored or represented. The real is in a continuous process of becoming, but as it passes, it leaves tracks and traces in bodies, objects, as well as novellas and stories, both told and written. It is to this stories that I now turn in my attempt to see how philosophical figurations can walk along the real.

\section{Narrating lines of flight}

What has been particularly striking for me when reading various journalistic and institutional publications and reports around migrant and refugee women 'travelling alone' is that nearly all of them base their observations and draw their conclusions on stories elicited through interviews. There is an underlying agreement about the power of the voice of the refugee woman 'travelling alone', who stands up and offers her story as a testament of her ordeals and suffering. ${ }^{11}$ I do not want to downplay the importance of such reports in raising awareness and calling for action vis-à-vis critical gender-based problems in situations and contexts of forced displacement. The scope of my research, however, is different. Taking up the force of narratives to respond to the real, rather than correspond with it (see Tamboukou 2010), I have asked migrant and refugee women to tell their story of being on the move. Following lines from Hannah Arendt's (1998) and Adriana's Cavarero's (2000) philosophies, I have encouraged them to tell stories of Who they are, as unique and unrepeatable human beings, and not of What they are - objectified 'refugees', 'victims', 'stateless subjects'. My argument is that the existential experiences of women on the move create a rich archive that can challenge and transpose the way we think, understand and conceptualize the subject of feminism. Following Honig's, important question about 'what problems might foreigners solve for us' $(2001,4)$, I explore questions and issues that displaced and uprooted women pose to feminist theory and praxis. In doing so, I follow storylines as they unfold, twist, break, stop and restart. I try and listen to the rhythm of stories as a way of getting entangled in the labyrinths of their meaning. Listening as a political practice and as a mode of understanding is thus entangled with the analytics of this paper, since narratives have the power of involving us in the dynamics of thinking differently, beyond what seems to be 'obvious' in the unfolding of any story (see Tamboukou 2020a). Moreover, stories are interwoven in the web of human relations and as feminist researchers, we need to find a position within it, so that we can be-in-the-world-with-others.

Life-stories create a design, a discursive unity that carries meaning, Arendt has argued, although this meaning is never fixed, but rather felt and lived $(1968,105)$. As poststructuralist feminists however, we have been raised to challenge any form of unity 'that necessarily implicates the traditional attributions of totality, fixity and 
exclusiveness', Kolozova has observed. $(2014,20)$ And yet it is the unity and continuity of women's voice and experience that challenges the conditions of forced displacement.

By recounting their stories, not only do displaced women claim their 'right to have rights' (Arendt 1976, 298), they actually grasp a passage and re-insert themselves in the world of human relations. But although Arendt maintains that 'this insertion is not forced upon us by necessity, like labor, and it is not prompted by utility like work' $(1998,176)$, displaced women's desire to tell their story proves her wrong. Women who participated in my research told me in no uncertain terms that they wanted to tell their story, so that their experiences would not be lost, that they wanted to shout out loud to the world about Who they are. In doing so they felt they connected with other women in overcoming difficulties and in joining in solidarity and struggle: 'I really needed to share my story with someone and I wanted to thank you for listening to me and I just expressed everything in the story' Somi, a refugee woman who fled an oppressive political regime, becoming a political exile when she was only 19 years old, told me at the end of her interview. ${ }^{12}$

Somi's desire to take her life back through her story, reminded me of Fred Moten's notion of 'stolen life' (2018) in its double articulation: a life that was stolen in the historical processes of transatlantic slavery - or of political exile in Somi's story - but also a life that steals itself back through action and narration. Making sense of migrant and refugee women's narratives through the lenses and insights of black feminist thought opens up paths in the wider project of decolonizing feminist theory, its concepts, formulations and figurations.

In further reflecting on Arendt's thought Honig has noted that 'the right to have rights could be seen as an authorizing ground for the claims made by those without proper standing to make them' (2001,61-62). This authorizing ground underpins a mode of political agency as taking and positions the immigrant as a political subject that makes contestable claims and take rights on her own behalf'. (ibid., 149, my emphasis). I have been particularly intrigued by this notion of agency as 'taking', particularly when listening to stories of 'grasping a passage' in the context of my research. As Nadia told me, 'when I came back, I kept one thing in my mind, I will not stay in this country, no, I need to go, I have to go.' ${ }^{13}$

Nadia is a young woman who was separated from her mother and sister while attempting to cross the Turkish/Greek borders. Staying back in Turkey, when she was only 15 , she was trapped in the slavery conditions of the Istanbul garment industry for 3 years. Soon after failing to register herself in Ankara as a minor asylum seeker at the time, Nadia went back to Istanbul determined to find a way to cross the borders on her own without 'having the right' to do so. In her story she talked passionately about how she literally 'grasped' her passage by saving money, by collecting information about the smugglers and by finally persuading the family she was working for, to let her go: 
I kept asking the girls, how much their brothers or their fathers pay to a smuggler and the patron's wife was telling me 'it's not easy, what you are thinking' [...] I said no, if your husband talks with a family and they could help me, I will pay of course, [...] I will pay for my way, if it is more money, I will not ask from you [...] and there was a nice family [...]। came to Greece with them, we came the land way in one container, 40 people, they allowed me to come with that family. ${ }^{14}$

Nadia's determination 'to go' took her to Greece, where she managed to register herself, find a place to leave, get an education and even start volunteering for refugee centres and organizations, helping other women to stand on their feet. More importantly she managed to trace her mother and sister and she ultimately joined them in Germany. Nadia's story seems to become an exemplar of Sandro Mezzarda's (2011) argument that we need to conceptualize migration not only as a plane of socioeconomic conditions and structures, but also as a field of creativity and forces, a space where politics can be re-imagined, a historical field of struggles, wherein mobility has played a major role.

Nadia's 'lines of flight' however, create a new pattern of movement, which is neither circular, nor aimless, nor aggressive. Because of its agential drives and cuts, through continental territories - Afghanistan, Iran, Syria, Turkey and finally Greece - Nadia's passage cannot be encompassed within Glissant's image of the errant slave ship either; it rather becomes what I want to call 'an arrowlike nomadism of escape'. Her border crossings can be taken as a political act of taking: 'the practice of taking rights and privileges rather than waiting for them to be granted by a sovereign power is, I would argue a quintessentially democratic practice' Honig has written $(2001,99)$.

Looking at the archive of migrant and refugee women's stories that my research has already created (Tamboukou 2020a), 'lines of flight' from war and patriarchal machines can be traced in all narratives, although their cartographies have specificities and nuances that create a diverse map of modalities of errance and nomadism. Sometimes a desire to leave was not targeted or specific: 'I don't know why, I just wanted to leave', Linda a Syrian woman told me about her decision to leave her brother's home in Turkey, where she had initially found refuge from the war and internal conflicts in Syria, get on a boat and sail to Greece. Her escape carries traces of multiple causalities and 'agential cuts'. When recounting her sea voyage to Greece, she talked about her strange anxiety in Turkey, her love of the Greek language, which she had studied at school, the excitement of making a new beginning as an independent woman, as well as the beauty of the Greek islands:

I remember now being on the boat after having being attacked by the Turkish police and when I looked ahead and saw the Greek coast, I thought, 'Oh, how beautiful Greece is!' Greece looked so beautiful to me and I thought then, 'am I going to die, before I reach Greece? No, there is no way I will die, I will definitely reach there.' It's true, that's how I felt, that's what I thought. ${ }^{15}$

Following Glissant, who talks about antillanité or Carribbeanness (1989), I have thus tried to consider entanglements between trauma and beauty while listening to stories 
of turbulent crossings of the Aegean sea. Although Linda could not fully explain what underpinned her decision to go to Greece, her story is rich, full of visual images, impressions, desires, affects and feelings, as well as fears and anxieties: an embedded and embodied cartography of entanglements between loss, pain, fear, escape, as well as the desire to create something new, a story in-between nomadism and errance.

What is also important to consider as a component of global mobility assemblages is an unprecedented backlash on women's rights around the world that range from women's overall marginalization in the global economy, threats and open attacks to abortion rights, gender-based violence and rape culture, trafficking and sexual slavery, moral panics and mobility restrictions that are both externally and internally imposed. The abject figure of the derailed male refugee and/or economic migrant has become not only the enemy of the state, but also women's enemy par excellence! As Honig has succinctly remarked, xenophobic feelings and attitudes often pass through 'concerns' for women, whose rights and bodies are in danger and need to be protected $(2001,65)$. Indeed, the media abound with horror stories and gender atrocities. ${ }^{16}$ What they convey is a culture of gender-based fear that is expressed through a return to women's spatial and mobility restrictions, an issue over which so much feminist ink has already been spilt.

In this context, the figuration of the nomad still carries symbolic possibilities for resistance in the ways I have already discussed in the previous sections of the paper. Discarding nomadism altogether therefore carries the risk of losing a strong concept that has opened up radical ways of thinking women in non-static ways, outside the boxes of domesticity, as non-place bound, and as not necessarily and essentially linked to 'motherlands' and 'fatherlands' of all sorts and renditions of nationalist discourses and practices. What is to be done then? How can we still imagine women following 'lines of flight'? And last but not least, how exactly can a non-philosophical approach to the concept of nomadism keep its relation to the real in all its unfolding complications and contingencies?

\section{Imagining the non-nomad}

In grappling with the aporias that the figuration of the nomad raises in moving alongside the real what I therefore suggest is a radical encounter between the nomad and 'uprooted women travelling alone'. What emerges from this encounter is the nonnomad, a figuration that retains the radical possibilities of unregulated and free movement while responding and reacting to the material conditions of displaced women's urgent precariousness. In bending Braidotti's figuration, I follow here her suggestion that constructing 'intellectually mobile requires an ethic of differential coding for the various modes and forms of mobility' $(2012,10)$

In experimenting with the notion of the non-nomad I take insights from the project of non-philosophy and particularly Kolozova's deployment of principles of nonphilosophy in theorizing female subjectivity, as already discussed in the previous section. Here the 'non' in nomadism is taken as a transposition, 'an intertextual, crossboundary or transversal transfer, in the sense of a leap from one code, field or axis into another' (Braidotti 2006, 5). The non-nomad then, does not negate nomadism, 
but rather points to its shadows and margins. As an emerging figuration, the nonnomad reassembles lines of flight within the restrictions of the real; she demythologises fictions of free movement without shattering its political imaginaries. Kolozova's notion of 'radical solitude' is crucial in mapping the positions, affects and practices of the non-nomad. 'Grief is a state of being exposed in one's constitutive dependence' (49) Kolozova notes in a fine summary of Judith Butler's late work on the political significance of grief (2004). But while agreeing with Butler about the political force of grief, Kolozova argues that grief is also, an instance of 'radical solitude' par excellence, encompassing 'the hard labour of self-preservation performed by the ' $I$ ' in the face of the dread of its possible annihilation $(2014,49)$. No matter how mobile or transient the self is, it works hard on preserving its continuity. This hard labour, the force of the Spinozist 'conatus', creates a state that is for Kolozova, 'an irrevocably solitary one' (ibid., 50). It was such moments of 'radical solitude' that have left their traces in displaced women's narratives: 'I remember when I was working in the textile, everyone was busy with the stitching and when I was walking around, so nobody could see me, my eyes were always full of tears, I was always crying, I was not happy at all'. ${ }^{17}$ I was quite drawn in the way Nadia recounts tearful moments of despair shortly before taking the decision to go away. As Kolozova writes, radical solitude encompasses instances of 'a self-enclosed reality of mere labour at a point where the organic and the sense of selfhood merge into each other' $(2014,50)$. Nadia's tears, as an embodied expression of pain merge here with a sense of who she wanted to be or rather to become. Her tears become material components of her self-preservation that is elusive to the authority of language, as well as to any philosophical figuration that attempts to grasp and theorize it.

Such stories of radical solitude have released forces of communication and correspondence, 'the identity in the last instance of the human-in-human [...] the real of the pure, non-reflected experience of being human' (Kolozova 2014, 108). It is here that Laruelle's notion of 'the Stranger' becomes crucial: 'one lives the destiny of the world through the solitary experience of living one's individual destiny of a Stranger' Kolozova has noted (ibid. 150). In Laruelle's conceptualization, we all become Strangers to our non-reflected lived experiences, le vécue, since at the very moment we start grappling with the world and attempt to map ourselves within it, we initiate a process of self-alienation from the real. Nadia's story leaves traces of this process of becoming 'a Stranger':

Life was not easy, you have to fight with life, I learnt this, otherwise I could not have got out of all those situations I had in my life, sometimes I felt I would kill myself, because when you don't have a home, when you don't have anything in your life, you think your life is useless. ${ }^{18}$

Autoalienation is repetitive and as it keeps going it leaves behind crystallized formations, psychosocial and material residues, memories and embodied habits, 'the stubborn fact of the past' (Whitehead 1985, 129) that gradually gives form to what we come to see and recognize as 'the self' or 'the subject'. There is thus a distinction between the real and 'the Stranger', which should not be taken as a split or as a duality, but rather as a parallel movement of self-differentiation, Kolozova pithily 
notes (see 2014, 115). The body is of course the immediate locus of the Stranger in his/her continuous interaction with and differentiation from the real, 'the site of that mute persistence of the self' (ibid.,153).

Perceived as 'a Stranger' in the radical solitude of grappling with the world, displaced women cannot escape the regulatory hold of mobility restrictions: their wanderings will be severely limited, impeded and even annihilated. Yet, it is in the very act of autoalienation and self-differentiation that displaced women are provisionally crystallized as non-nomads, restricted in their actual mobility but free in their radical immanence to imagine a different position in the world and act on it: dare live for the world and not in it, as Laruelle and Schmid have aptly put it $(2003,55)$. Hanna's agony to surpass her fear of public speaking in her struggle to get a residence permit and avoid deportation, vividly displays this process of self-differentiation:

For me, for African women, it is very difficult to speak in public because in Africa when I was there, everything you do, they tell you, 'shut up, you are a woman, what do you want to say?' So, when they asked me to get up and speak in public, I said 'I cannot do that, I cannot do that', two times. But the second time, when I got home $\sim$ because, whenever I have a problem, I talk to myself, I talk to myself, really I said, 'look, what do you want now? Are you going to speak in public, or are you going to leave without a residence permit? Just think about that... I told myself decide, here is not Africa, decide, what are you going to do?' And then I decided, I said, 'no problem, I will speak'. ${ }^{19}$

Hanna's story beautifully dissects the moment of differentiation by staging a dialogue between two of the many sides of the self: 'to speak or not to speak?' The dilemma is rooted in some essentialist perceptions and expressions of 'the African woman self', who neither speaks, nor moves easily. However, the desire and need to protect the self against annihilation gears her lines of flight, deterrotorializes her from the dark holes of patriarchy - 'shut up, you are a woman' - and throws her into the adventure of public speaking and political activism. Hanna's decision to speak was the start of an agonistic path that has founded amongst others a powerful organization for African women's rights in Greece. Refugee and migrant women's amazing stories of survival, perseverance and continuing movement despite all odds and adversities, are a testament of the force of non-nomads in their alignment with the real.

\section{Re-imagining language and the subject}

Following Wittgenstein's lyrical remark that 'to imagine a language is to imagine a new form of life' $(1986,8)$ in this paper I have problematized the nomad as a name, a word, a descriptor, but also as a figuration. What I have argued is that the real of the current global mobility assemblages and particularly women's position within them, has raised urgent questions that need to be addressed within the old project of reimagining the subject of feminism. While pointing to its nominalist correlations with privileged mobility, I have nevertheless acknowledged the political imaginaries of radical and unregulated movement that the figuration of the nomadic subject has inspired in the field of critical feminisms. Here I have drawn on Glissant's philosophical 
thought and poetics to map modalities of nomadism within particular geographies and histories, the so called 'Mediterranean crisis' in the case of this paper.

While Glissant's notion of the errance encompasses the wanderings of the slave ships in the openness of the Atlantic, the closeness of the Mediterranean sea and the proximity of the Greek islands to the shores of Turkey has created geographical conditions for new modalities of nomadism, yet to be charted. While I have traced lines of 'arrowlike nomadisms of escape' in some of the stories that comprise the archive of my research (Tamboukou 2020b), my argument is that every story needs its own cartography, if we want to really make sense of continuously emerging and changing mobility assemblages of our geographies and times. Moreover, the geopolitical conditions underpinning particular modalities of nomadism do not necessarily create a plane for 'a nomadic subject' to emerge as a figuration that can encompass the precarity of migrant and refugee women's travels today. Nomadism, alongside errance and other modalities of wandering, yet to be charted, are rather taken as components of entangled relations within mobility assemblages at work.

In further recognizing the constitutive character of names and words, as well as the political effects of 'language games', I have suggested that the figuration of the nonnomad can bridge gaps between thought and the real. In doing so I have followed some trails of Laruelle's non-philosophy, particularly as it has been deployed in Kolozova's theorization of gendered subjectivities. I have done so, while taking nonphilosophy as a site of experimentations and not as a doctrine or a closed theoretical framework.

In suggesting this nominal play between the nomad and the non-nomad I have followed Koggel's suggestion that such imagining points to 'the endless possibility and variety of language games but also demonstrates just how complicated the description of some activities can become' $(2002,239)$. If we accept Wittgenstein's argument that language games are practices that do more than denote or describe, creating a political vocabulary that is more sensitive to the demands of the real might contribute to the overall project of changing the real, by pointing to its shadows and exclusions, both real and nominal.

\section{Acknowledgements}

I would like to thank the Leverhulme Trust for supporting this research through a Research Fellowship grant [RF-2018-212\8]. My deepest gratitude goes to the women, who offering me the gift of their story.

\section{References}

Baaten, Jane. 2002. 'The short life of meaning'. In Feminist Interpretations of Ludwig Wittgenstein, edited by Naomi Scheman and Peg O'Connor, 176-192.

Philadelphia: Pennsylvania State University Press. 
Tamboukou, Maria.2020. 'Feeling the real: the non-nomadic subject of feminism. Theory, Culture and Society', forthcoming

Baker, Nancy. 2002. 'Wittgenstein, Feminism, and the Exclusion of Philosophy'. In In Feminist Interpretations of Ludwig Wittgenstein, edited by Naomi Scheman and Peg O'Connor, 48-64. Philadelphia: Pennsylvania State University Press.

Boer, Inge (1996) 'The World Beyond Our Window: Nomads, Travelling Theories and the Function of Boundaries', Parallax 3: 7-26.

Boswell, Christina, Geddes, Andrew, Scholten Peter. 2011. 'The Role of Narratives in Migration Policy-Making: A Research Framework'. The British Journal of Politics and International Relations. 13(1), 1-11.

Braidotti. Rosi. 2002. Metamorphoses : Towards a Materialist Theory of Becomings. Cambridge: Polity.

Braidotti. Rosi. 2006. Transpositions : On Nomadic Ethics. Cambridge : Polity Press.

Braidotti, Rosi. 2011. Nomadic Subjects: Embodiment and Sexual Difference in Contemporary Feminist Theory. $2^{\text {nd }}$ edition. New York: Columbia University Press.

Braidotti, Rosi. 2012. Nomadic Theory, The Portable Rosi Braidotti. New York: Columbia University Press.

Burrell, 2017. Kathy. Moving Lives: Narratives of Nation and Migration among Europeans in Post-War Britain. London: Routlrdge.

Butler, Judith. 2004. Precarious Life: the Powers of Mourning and Violence. London: Verso.

Carastathis, Anna, Aila Spathopoulou, Myrto Tsilimpounidi. 2018. 'Crisis, What Crisis? Immigrants, Refugees, and Invisible Struggles, Refuge, 34 (1), 29-38.

Cavarero, Adriana. 2000 [1997]. Relating Narratives: Storytelling and Selfhood. Translated by Paul A. Kottman. London: Routledge.

Deleuze, Gilles and Guattari, Felix. 1988. [1980] A Thousand Plateaus: Capitalism and Schizophrenia, trans. Brian Massumi. London: The Athlone Press.

Foucault, Michel. 1991 [1969]. The Archaeology of Knowledge, trans Alan. M, Sheridan Smith. London: Routledge.

Gabaccia Donna.1999. 'Is Everywhere Nowhere? Nomads, Nations, and the Immigrant Paradigm of United States History. The Journal of American History 86 (3), 1115-1134.

Gedalof, Irene. 1996. 'Can Nomads Learn to Count to Four? Rosi Braidotti and the Space for Difference in Feminist Theory'. Women: A Cultural Review 7(2), 189201.

Gedalof, Irene. 2000. 'Identity in Transit: Nomads, Cyborgs and Women'. European Journal of Women's Studies 7, 337-54.

Glissant, Édouard. 1989 [1981]. Carribean Discourse. Selected Essays. Trans. Michael Dash. Charlotesville: University of Virginia Press.

Glissant, Édouard. 2010 [1990]. Poetics of Relation. Trans. Betsy Wing. Ann Arbor: The University of Michigan Press.

Hacking, Ian. 1986. 'Making Up People'. In Reconstructing Individualism: Autonomy, Individuality and the Self in Western Thought, ed.Thomas C. Heller, Morton Sosna, and David E Wellbery, 222-236. Stanford: Stanford University Press.

Hesford, Wendy. 2011. Spectacular Rhetorics: Human Rights Visions, Recognitions, Feminisms. Durham: Duke University Press.

Honig, Bonnie. 2001. Democracy and the Foreigner. New Jersey: Princeton University Press. 
Tamboukou, Maria.2020. 'Feeling the real: the non-nomadic subject of feminism. Theory, Culture and Society', forthcoming

Kaplan, Caren. 1987. 'Deterritorializations: The Rewriting of Home and Exile in Western Feminist Discourse'. Cultural Critique 6 (187-198).

Kinkaid, Eden. 2019. Can assemblage think difference? A feminist critique of assemblage geographies. Progress in Human Geography, 44(3): 457-472.

Koggel, Christine M. 2002. 'Using Wittgensteinian Methodology to Elucidate the Meaning of Equality'. In Feminist Interpretations of Ludwig Wittgenstein, ed. Naomi Scheman and Peg O'Connor, 235-258. Philadelphia: Pennsylvania State University Press.

Kolozova, Katerina. 2014. Cut of the Real: Subjectivity in Postructuralist Theory. New York: Columbia University Press.

Laruelle, François. 2013 [1996]. Principles of Non-Philosophy, trans. Nicola Rubczak and Anthony Paul Smith. London: Bloomsbury.

Laruelle, François and Anne Françoise Schmid. 2003. 'L' identité sexuée' Identities 2(3), 49-61.

Mezzarda, Sandro. 2011. The Gaze of Autonomy. Capitalism, Migration and Social Struggles. In Squire V. (ed) The Contested Politics of Mobility: Borderzones and Irregularity. London: Routledge, 121-143.

Moten, Fred. 2018. Stolen Life. Durham: Duke University Press.

Mullarkey, John and Anthony Paul Smith, eds. 2012. Laruelle and Non-Philosophy. Edinburgh: Edinburgh University Press.

Riley, Denise. 2005. Impersonal Passion: Language as Affect. Durham and London: Duke University Press.

Scheman, Naomi. 1993. Engenderings: Constructions of Knowledge, Authority and Privilege. New York: Routledge.

Smith, Anthony, Paul. 2016. Laruelle: A Stranger Thought. Cambridge: Polity Press.

Stengers Isabelle. 2008. A constructivist reading of Process and Reality. Theory, Culture and Society 25(4): 91-110.

Tamboukou, Maria. 2003. Women, Education, the Self: a Foucauldian perspective. Basingstoke: Palgrave, Macmillan.

Tamboukou, Maria. 2009. 'Leaving the self, Nomadic passages in the memoir of a woman artist. Australian Feminist Studies, 24:61, 307-324.

Tamboukou, Maria. 2010. Nomadic Narratives, Visual Forces: Gwen John's letters and paintings. New York: Peter Lang.

Tamboukou, Maria. 2012. 'Heterotopic and Holey Spaces as Tents for the Nomad: Rereading Gwen John's Letters'. Gender, Place and Culture: A Journal of Feminist Geography, 19 (3), 275-290.

Tamboukou, Maria. 2018. 'Revisiting the nomadic subject', a Leverhulme funded research project, https://sites.google.com/view/revisiting-the-nomadic-subject [Accessed, 23 June, 2020]

Tamboukou, Maria. 2020b. 'Narrative Rhythmanalysis: the art and politics of listening to women's narratives of forced displacement'. International Journal of Social Research Methodology, doi: 10.1080/13645579.2020.1769271, on-line first.

Tamboukou, Maria. 2020b. 'Mobility assemblages and lines of flight in women's narratives of forced displacement'. European Journal of Women's Studies, doi/10.1177/1350506820932946 (on-line first) 
Tamboukou, Maria.2020. 'Feeling the real: the non-nomadic subject of feminism. Theory, Culture and Society', forthcoming

Wittgenstein, Ludwig. 1986 [1953]. Philosophical Investigations, trans. G.E. M. Anscombe. Oxford: Blackwell.

Woolf, Virginia. 1978 [1938] Three Guineas. London: Penguin.

Whitehead, Alfred North. 1964. The Concept of Nature: The Tarner Lectures. Delivered in Trinity College. November 1919. Cambridge: Cambridge University Press.

Whitehead, Alfred, North. 1985. [1929] Process and Reality [Corrected Edition], ed. David Ray Griffin and Donald W. Sheburne. New York: The Free Press.

Wuthnow, Julie. 2002. 'Deleuze in the Postcolonial: On Nomads and Indigenous Politics'. Feminist Theory, 3(2), 183-200.

Yountae, An. 2014. Beginning in the Middle: Deleuze, Glissant, and Colonial Difference. Culture, Theory and Critique, 55(3), 286-301

Zavos, Alexandra. 2017. 'Intersections and Cross-Fertilizations between Feminist Research and Refugee Studies', Annual Review of Critical Psychology, 13, 1-6.

\footnotetext{
${ }^{1}$ Kolozova's take of 'the real', follows Laruelle's non-philosophy: 'that which is outside interpretation, outside the cognitively created reality' $(2014,155)$.

${ }^{2}$ http://www.coe.int/en/web/commissioner/-/human-rights-of-refugee-and-migrant-women-andgirls-need-to-be-better-protected [Acessed, May 16, 2016]

${ }^{3}$ The project of non-philosophy cannot be presented and discussed in detail within the restrictions of this paper. There is currently an important body of primary and secondary literature around nonphilosophy. See amongst others: Mullarkey and Smith 2012; Laruelle 2013; Kolozova 2014; Smith 2016

${ }^{4}$ See Boer 1996; Gedalof 1996, 2000; Kaplan 1987; Wuthnow 2002.

${ }^{5}$ There is a growing body of literature making connections between Glissant and Deleuze and Guattari, particularly in the field of decolonial studies. See amongst others, Drabinsky 2011; Drabinsky and Parham 2015; Yountae 2014.

${ }^{6}$ Hanna's story Athens, December 2018.

${ }^{7}$ Nadia's story, Athens, July, 2018.

${ }^{8}$ http://www.unhcr.org/uk/protection/operations/569f8f419/initial-assessment-report-protectionrisks-women-girls-european-refugee.html [Accessed, May 6, 2016]

${ }^{9}$ There is a growing body of secondary literature around assemblages today in philosophical, political and social analytics, as well as different takes of it. (see Kinkaid 2020 for the most recent overview of this literature).

${ }^{10}$ See amongst others, Donato and Gabaccia 2015, Castles 2006.

${ }^{11}$ See for example Oumo's story at http://www.unhcr.org/uk/protection/operations/569f8f419/initial-assessment-report-protectionrisks-women-girls-european-refugee.html [Accessed, May 6, 2016]

12 Somi's story, Athens, December, 2018.

${ }^{13}$ Nadia's story, Athens, July, 2018.

14 Ibid.

${ }^{15}$ Linda's story, Lesvos, April 2019.

${ }^{16}$ See for example, http://www.dailymail.co.uk/news/article-3390168/Migrant-rape-fears-spreadEurope-Women-told-not-night-assaults-carried-Sweden-Finland-Germany-Austria-Switzerland-amidwarnings-gangs-ordinating-attacks.html [Accessed, 12-2-2017]

${ }^{17}$ Nadia's story.

18 Ibid.
} 
Tamboukou, Maria.2020. 'Feeling the real: the non-nomadic subject of feminism. Theory, Culture and Society', forthcoming

${ }^{19}$ Hanna's story. 